\title{
Impact of Demonetization on Indian Economy: A Survey
}

\author{
Rinku Tiwari (Research Scholar), Dr Rajesh Manchanda, \\ Associate Professor, OIMT (Rishikesh) Dr. Neeraj Rawat, Director (Outreach, \\ Learning \& Development) UPES, Dehradun \\ Uttarakhand Technical University, Suddhowala, Dehradun 248 001, Uttarakhand, India
}

\begin{abstract}
Currency Demonetization has taken the world by surprise. It expressed the commitment of the Indian Government in cracking a whip on the black money and flushing out the fake money. The present Government has demonetized Rs.500 and Rs.1,000 denomination notes in circulation and ushered in a sleuth of reforms that directly addresses the common man, economy, business and global relations. Interestingly, there are views that both supports and argues on the currency demonetization in India. This debate will provide a forum for students to talk for and against the demonetization of higher denomination currencies in India.
\end{abstract}

Key Words: Prime Minister Modi, Mahayajna, Economic Liberty, Currency Notes, Demonetization, Black Money, Electronic Payment Systems, Fake Currency, GDP Growth, Inflation, Undocumented Transactions, Tax Evasion, Loan Burden, Monetary Transmission, Share Indices.

\section{Introduction}

In a 40 minute long speech Prime Minister Narendra Modi announced the demonetization of existing notes of Rs 500 and Rs 1000 during a televised address on Tuesday evening. Modi announced that the notes of Rs 500 and Rs 1000 "will not be legal tender from midnight tonight" and these will be "just worthless pieces of paper. PM also urged people to 'join this mahayajna against the ills of corruption. In an effort to combat corruption, tax evasion and counterfeiting, all 500 and 1,000 rupee banknotes are no longer recognized as legal tender. Electronic payment systems are convenient, fast and easy, but when a government imposes this decision on you, your economic liberty is debased. In a purely electronic system, every financial transaction is not only charged a fee but can also be tracked and monitored. Taxes can't be levied on emergency cash that's buried in the backyard. Central banks could drop rates below zero, essentially forcing you to spend your money or else watch it rapidly lose value.

Inevitably, low-income and rural households have been hardest hit by Modi's currency reform. Barter economies have reportedly sprung up in many towns and villages. Banks have limited the amount that can be withdrawn. Scores of weddings have been called off. Indian stocks plunged below their 200-day moving average.

\section{What Is Demonetization}

Demonetization is the process of devaluing a piece of currency to zero. In other words, changing the value of a particular denomination of currency to nil, making it a piece of paper with absolutely no value greater than a regular piece of paper. Demonetization for us means that Reserve Bank of India has withdrawn the old Rs 500 and Rs 1000 notes as a official mode of payment. According to Investopedia, demonetization is the act of stripping a currency unit of its status as legal tender.

\section{What was the reason?}

The reasoning given by Modi was:

1. To tackle black money in the economy.

2. To lower the cash circulation in the country which "is directly related to corruption in our country, " according to PM Modi.

3. To eliminate fake currency and dodgy funds which have been used by terror groups to fund terrorism in India.

4. The move is estimated to scoop out more than more than Rs. 5 lakh crore black money from the economy, according to Baba Ramdev, a staunch Modi supporter.

Now let us consider the situation and try to analyze the situation in terms of the economy and financial position of India. 


\section{Why India Demonetized 2 Currency Notes \\ Indian government's surprise}

In an address to the nation on November 8, India's prime minister, Narendra Modi, declared that the two highest denomination currency notes - the 500 rupee note and the 1,000 rupee note-won't remain legal tender. The notes were demonetized at midnight on November 8 . The move aimed to curb black money in the financial system. Black money is one of the factors holding back the economy. The demonetization was a surprise. Since the announcement, the media discussed the pros and cons for consumers and the banking system (HDB) (IBN).

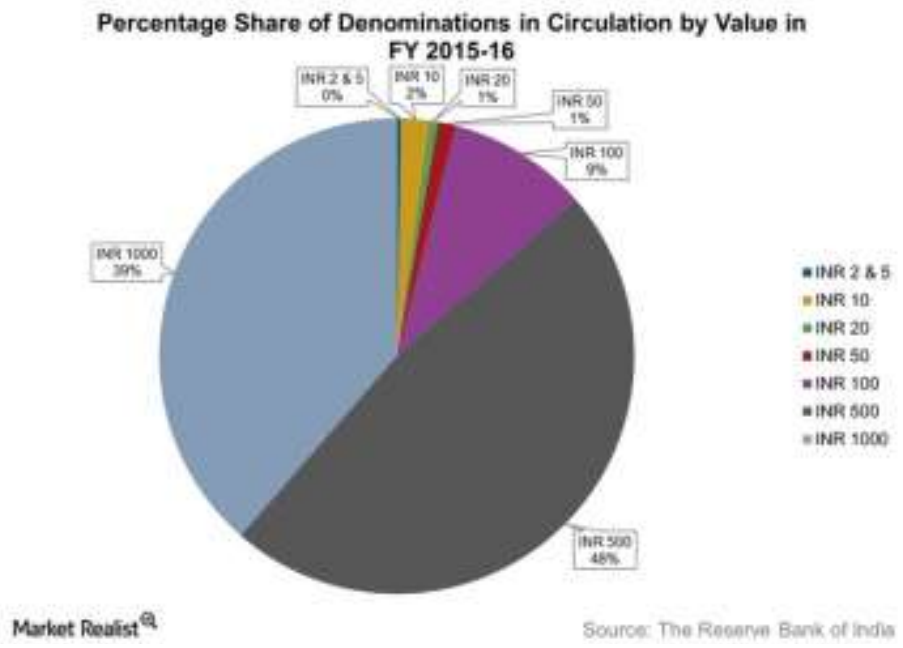

\section{Lion's share put out of circulation}

According to the RBI's (Reserve Bank of India) Annual Report for April 2015 to March 2016, the value of the currency notes at the end of March 2016 was 16.42 trillion Indian rupees. The 500 rupee and 1,000 rupee currency notes formed $86.4 \%$ of the value. In one stroke, the government removed $86.4 \%$ of the currency in circulation by value. In terms of volume, the currency notes of these two denominations formed $24.4 \%$ of a total 90.27 billion pieces.

Also, RBI data showed that as of March 2016, 632,926 currency notes were counterfeit - known as an FICN (Fake Indian Currency Note). As a proportion of NIC (Notes in Circulation), the 1,000 rupee and 500 rupee notes were the highest. Nullifying these FICNs was also part of the demonetization move.

\section{How Could Demonetization Impact the Indian Economy? Demonetization will hit the economy}

The demonetization of the 500 rupee note and the 1,000 rupee note-the two highest currency denominations available in India - will likely hit the economy hard in the short term. The surprise move is expected to grind the consumption activity in the Indian economy to a virtual halt. The service sector, which dominates economic activity and involves a sizable chunk of cash transactions, will likely be hit the hardest.

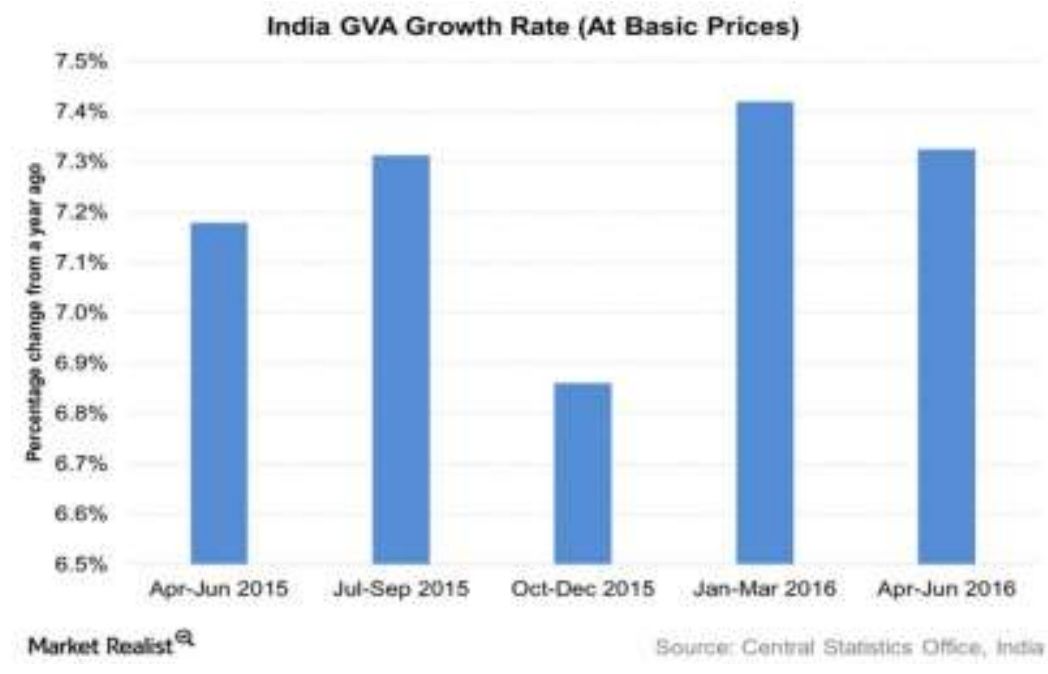




\section{India's economic growth}

Growth in the Indian economy remained solid in the quarter from April to June 2016 (the latest available). In India, a financial year begins in April and ends in March of the following year. The previously mentioned quarter is the first quarter of fiscal 2016-2017. During that period, the GDP (gross domestic product) rose $7.1 \%$, while the GVA (gross value added) rose $7.3 \%$. The relationship between the GDP and GVA is: GDP $=$ GVA + taxes on products - subsidies on products

The base year for calculating the GVA is 2011-2012.

The fall in economic activity due to demonetization could last from two to three quarters. As a result, GDP and GVA growth in the quarters from September to December 2016 and January to March 2017 could be significantly lower than previous years. Some bounce back should be seen in the first quarter of fiscal 20172018. In the medium term, the Indian economy can grow considerably after curbing the debilitation caused by counterfeit money and an increase in economic activity.

\section{Will Demonetization Impact India's Inflation? \\ Measures of inflation in India}

The RBI (Reserve Bank of India) considers the CPI (consumer price index) as its primary gauge of measuring inflation. Prior to the RBI adopting the CPI in India (PIN) (FINGX), another measure of inflationthe WPI (wholesale price index) — was the key gauge of inflation and it's still considered for reference. To learn more about these measures of inflation, read India's different inflation measures-WPI versus CPI.

The RBI has CPI growth targets to adhere to while deciding its monetary policy stance. By January 2016, it was supposed to keep inflation below a target of $6 \%$, which it was able to do. Its next target is to keep inflation at or below the 5\% mark by March 2017.

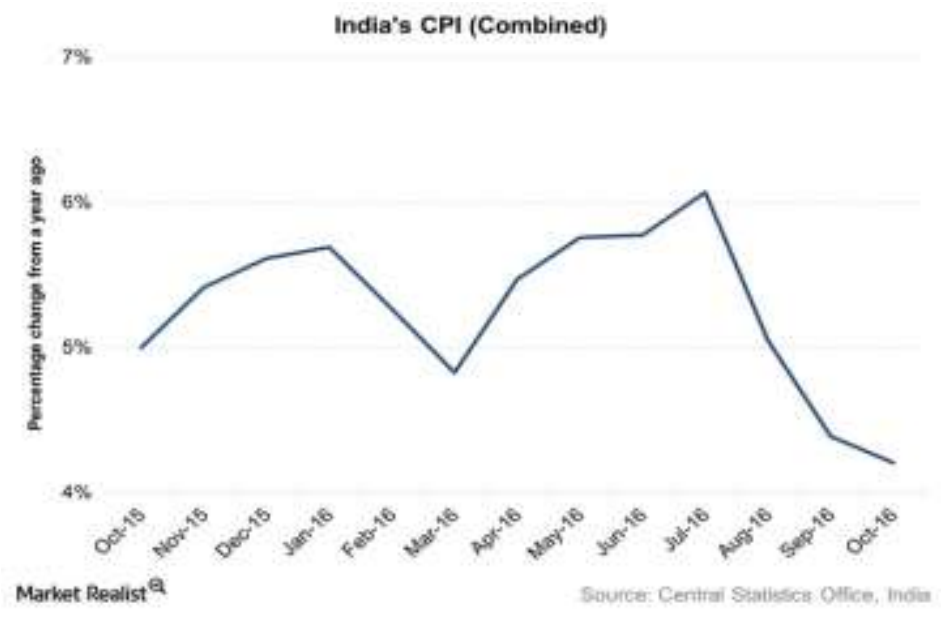

\section{Impact of Demonetization}

The demonetization that has been in effect since November 9 is expected to have a negative impact on inflation. Consumer spending activity fell to a near halt. Consumers are refraining from making any purchases except essential items from the consumer staples, healthcare, and energy segments. Activity in the real estate sector, which includes a lot of cash and undocumented transactions, slowed down significantly, Metropolitan and Tier 1 cities reported up to a $30 \%$ fall in house prices.

Food item inflation, measured by changes in the Consumer Food Price Index, accounts for $47.3 \%$ of the overall CPI. Due to $86.4 \%$ of the value of the currency notes in circulation going out of the financial system and re-monetization being slow, the supply and demand of food items fell. It will exert more downward pressure on inflation. Investors in India-focused funds (EPI) (WAINX) should continue to monitor CPI inflation. It will determine future rate cuts by the RBI. A change in the repo rate will impact interest rate-sensitive sectors and industries like financials (HDB) (IBN) and automobiles (TTM), among other sectors like the tech (WIT) (INFY) sector.

\section{RBI Cut the Repo Rate: Will More Rate Cuts Follow?}

Repo rate cut

In its last policy meeting on October 4, the RBI's (Reserve Bank of India) Monetary Policy Committee reduced the country's repo rate by 25 basis points on October 4, 2016. The rate reduced $6.3 \%$ from the said date. The October meeting marked the second rate cut in 2016. The combined quantum of the cuts for the year stands at 50 basis points. 


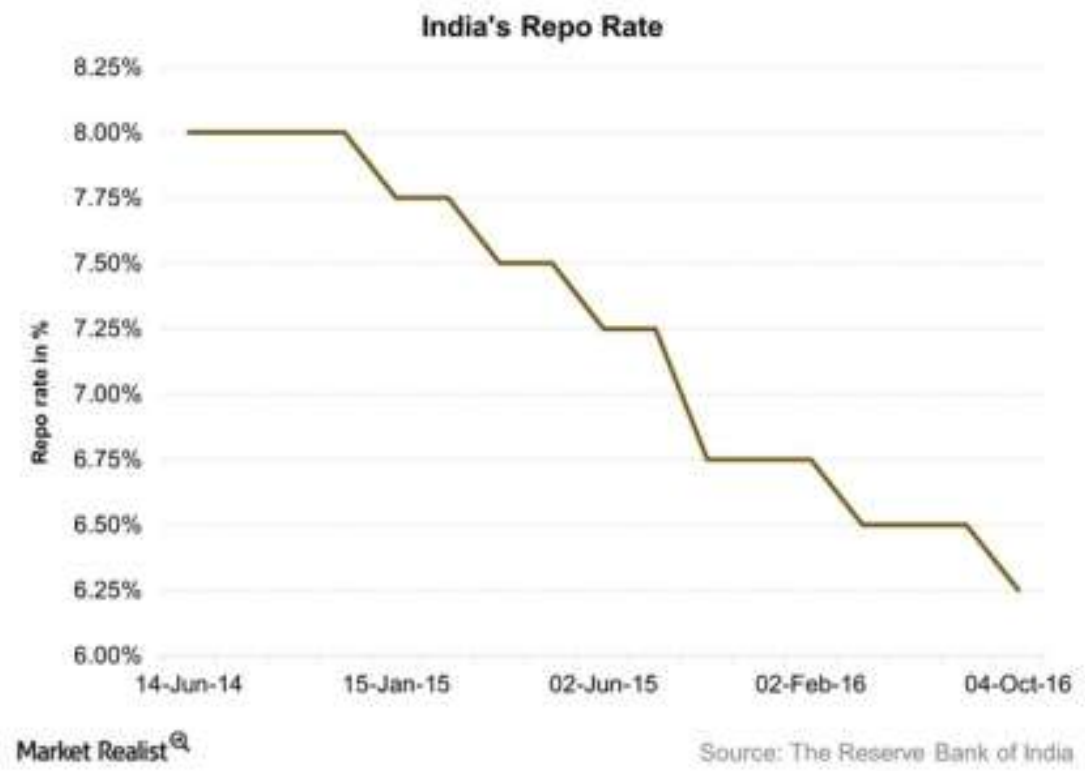

The repo rate, or repurchase option rate, is the key monetary policy rate for the RBI. It's the rate at which the RBI lends to commercial banks. The reverse of the repo rate- the rate at which banks park money with the central bank-is known as the "reverse repo rate."

A change in the repo rate signals an increase or decrease in rates to commercial banks (IBN) (HDB). Other rates, like the reverse repo rate and the MSF (marginal standing facility), are fixed against the repo rate. The rate impacts the movement of the rupee, which impacts the revenue of exporters and tech companies (WIT). It feeds into India-focused funds (ETGIX) (INDA) as well.

\section{More rate cuts to follow}

With the announcement of demonetization and the subsequent impact on cash transactions and consumption, inflation will likely fall. Banks already started reducing their deposit rates. Lending rates are expected to fall as well. Due to the expected fall in inflation, the RBI will likely undertake more cuts in the repo rate. These rate cuts will aim to boost consumption. They will work to get the temporarily derailed economic growth back on track. A cut in interest rates boosts economic activity and raises hopes that after a lull for two to three quarters, economic growth will rise.

\section{Will Demonetization in India Impact Your Loan Burden?}

Rates are already on the decline

After the demonetization announcement on November 8, Indian banks saw a rise in deposits. According to data from the Reserve Bank of India released on November 21, deposits crossed the 5 trillion rupee mark from November 10 until November 18. At 68.2 rupees to one US dollar, it translates to $\$ 75$ billion in deposits in just eight banking days.

Banks also saw a rise in term deposit accounts since the demonetization. Due to these factors, commercial banks like State Bank of India, ICICI Bank (IBN), HDFC Bank (HDB), and Punjab National Bank, among a host of others, sharply reduced their deposit rates.

\section{Loan burden will also fall}

Apart from cutting deposit rates, banks reduced their lending rates as well. In India, loans sanctioned from April 1 are with reference to the MCLR (Marginal Cost of funds-based Lending Rate), instead of the Base Rate, which was used earlier. It will translate into lower interest rates on existing floating rate loans and new loans. The reduction in lending rates is expected to stoke lending by tempting consumers to take out loans for purchasing expensive consumer discretionary items like vehicles and houses.

\section{Demonetization can help monetary transmission}

Monetary policy transmission is the translation of monetary policy actions into the financial system through banking and trading channels. The RBI (Reserve Bank of India) has been on a rate reduction cycle since January 2015. Before the January 2015 meeting, the repo rate stood at 8\%. Its journey from that level to $6.3 \%$ currently includes six rate cuts totaling 175 basis points. However, banks have been slow in transmitting the benefit to consumers. 
After being flush with deposits, it's expected that banks will reduce their lending rates sizably, improve monetary transmission, and benefit consumers-both corporate (RDY) (VEDL) (WIT) and individual. Any increase in economic activity due to more consumption on account of lower rates can be beneficial to Indiafocused funds (EPI) (FINGX) as well.

In the next part, let's see how demonetization could impact India's financial markets.

\section{India's Financial Markets Fell Due to Demonetization}

Equities fall, but prospects are better

Indian equity markets have been on a near secular falling trend since the government demonetized the 500 rupee and 1,000 rupee currency notes after midnight on November 8, 2016. The two benchmark equity indices - the Nifty 50 and the S\&P BSE Sensex - fell on each trading day since the demonetization except for November 10 and November 22. While the Nifty 50 fell $6.3 \%$ from November 8 until November 22, the S\&P BSE Sensex fell $5.9 \%$ during the same period. Due to the rise in the US dollar, the dollar equivalents of the Sensex and the Nifty fell more than $8 \%$ each.

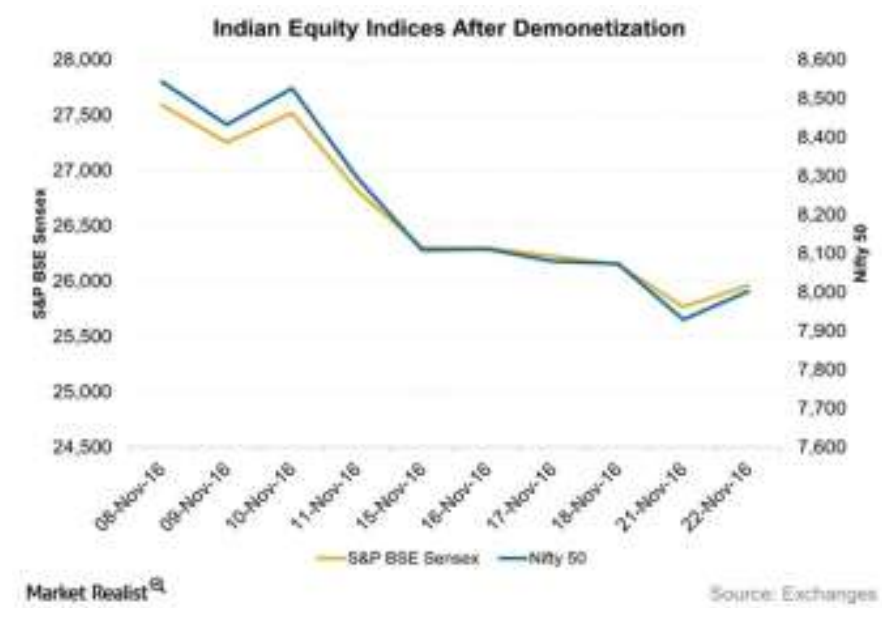

The S\&P BSE 100 Index, which is comprised of 100 stocks compared to the Sensex's 30, fell $6.6 \%$ during this period. Mid and small-cap indices have been hit much harder than broader market indices. Even after a rise on November 22, the S\&P BSE MidCap and the S\&P BSE SmallCap indices fell 8.2\% and 10.9\%, respectively, in the previously mentioned period. Apart from concerns about demonetization, Donald Trump's victory and concerns about his restrictive trade philosophy led to foreign investors pulling out of Indian equities. According to Bloomberg, foreign investors have net sold Indian equities (PIN) (INDA) worth \$1.4 billion from November 9-17.

However, once the short-term impact of demonetization is over, Indian equities will likely bounce back sharply. A rate cut from the Reserve Bank of India would be helpful and easy monetary conditions are generally beneficial for equities. Consumption-driven sectors and stocks (TTM) (VEDL) will continue to be hit in the short term.

Indian rupee fell

The Indian rupee fell against the US dollar. It mainly fell due to Donald Trump's victory in the US presidential election. Given the pressure on the local unit and its relative stability, it seems like the Reserve Bank of India has been working hard to keep the currency stable. India's tech companies (INFY) (WIT) saw a sharp correction since the demonetization was announced. However, the rupee's weakness can benefit these stocks. For now, Donald Trump's trade philosophy will be the main driver of the Indian unit.

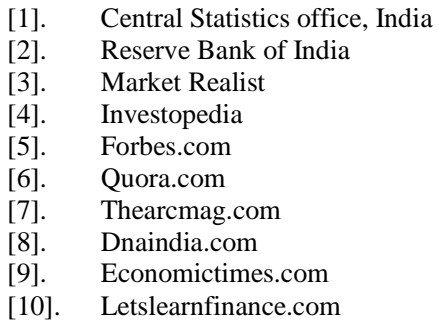

\section{References}

